\title{
Associations between thyroid function and mortality: the influence of age
}

\author{
Annenienke C van de Ven ${ }^{1}$, Romana T Netea-Maier', Femmie de Vegt ${ }^{2}$, H Alec Ross ${ }^{3}$, \\ Fred C G J Sweep ${ }^{3}$, Lambertus A Kiemeney ${ }^{2,4}$, Johannes W Smit ${ }^{1}$, Ad R Hermus ${ }^{1}$ and \\ Martin den Heijer ${ }^{1,5}$
}

${ }^{1}$ Division of Endocrinology, Department of Medicine, ${ }^{2}$ Department for Health Evidence, ${ }^{3}$ Department of Laboratory Medicine and ${ }^{4}$ Department of Urology, Radboud University Medical Centre, PO Box 9101, 6500 HB Nijmegen, The Netherlands and ${ }^{5}$ Section of Endocrinology, Department of Internal Medicine, VU University Medical Center, Amsterdam, The Netherlands
Correspondence should be addressed to A C van de Ven Email

Annenienke.vandeVen @radboudumc.nl

\begin{abstract}
Objective: The aim of this study was to investigate the influence of age on the association between thyroid function and mortality.

Design: The Nijmegen Biomedical Study is a population-based study, comprising 5816 randomly selected adults of all age groups without previously known thyroid disease.

Methods: TSH, free thyroxine $\left(\mathrm{FT}_{4}\right)$ and peroxidase antibodies were measured in 2002-2003. The number of deaths were established in 2012 (median follow-up time 9.4 years).

Results: Subclinical thyrotoxicosis was associated with mortality in subjects aged $<65$ years (hazard ratio (HR) $2.5,95 \% \mathrm{Cl}$ 1.1-5.7), but not in subjects aged $>65$ years. As for thyroid function within the normal range: in the 493 participants aged 80 years or older, an $\mathrm{FT}_{4}$ level in the high-normal range (18.5-22 pmol/l) was associated with a higher mortality in comparison with $\mathrm{FT}_{4}$ levels in the middle range (11.5-15.0 pmol/l): $\mathrm{HR} 1.7$ (95\% Cl 1.0-2.9). In these elderly, TSH levels within the highnormal range (3.0-4.0 mIU/I) were also associated with a higher mortality in comparison with TSH levels within the middle range (1.0-2.0 mIU/l): HR 1.8 (95\% Cl 1.0-3.1).

Conclusions: The relationship between thyroid function and mortality differs according to age. This finding might (partially) explain the discrepant results of previous studies examining the relationship between thyroid function and mortality in different age groups.
\end{abstract}

\section{Introduction}

Thyroid function disorders are common in the general population. The prevalence varies among different populations, depending on the iodine intake of the population. Overt thyroid dysfunction is associated with several cardiovascular risk factors, morbidity and mortality $(1,2)$. Subclinical thyroid function disorders are also associated with cardiovascular risk factors and cardiovascular diseases, although the associations are generally less strong and more controversial due to conflicting results in numerous studies $(3,4)$. Whether subclinical thyroid dysfunction is associated with mortality remains controversial, with some studies finding an association between mortality and subclinical hypothyroidism $(5,6,7,8,9,10)$ and/or subclinical hyperthyroidism (7), while other studies do not confirm these results $(11,12,13,14,15)$. Recently, six meta-analyses have reported conflicting results. These studies had to deal with clinical heterogeneity among the studies due to differences in both the included populations and methods of adjustment for confounders $(16,17,18,19,20,21)$.

In the past few years, the effects of thyroid function within the reference range on various biological
(ㄷ) 2014 European Society of Endocrinology Printed in Great Britain
Published by Bioscientifica Ltd. 
parameters have been studied (22). Only few studies investigated the relationship between thyroid function within the normal range and mortality. These studies also reported conflicting results $(23,24,25,26,27,28,29)$. Some found a positive association between mortality and blood thyroid-stimulating hormone (TSH) concentration within the normal range (23), whereas others found a negative $(24,28)$ or no association $(25,26,27,29)$. In addition, a positive association between mortality and free thyroxine $\left(\mathrm{FT}_{4}\right)$ within the normal range has been reported in the elderly $(24,27,29)$.

These latter studies suggest that age might influence the association between thyroid function and mortality. However, the total number of young participants and oldest elderly are limited in most studies. Some studies, including two meta-analyses, found an association between subclinical thyroid dysfunction and mortality in younger, but not in older subjects $(9,17,18)$. Furthermore, the results of the Leiden $85+$ Study suggest a protective effect of higher TSH levels in the oldest elderly (24). Other studies could not confirm this effect, but they did show a beneficial effect of lower $\mathrm{FT}_{4}$ levels, even within the normal range, in the elderly $(27,29)$. Most studies have been carried out in iodine-sufficient populations, in which TSH increases with age. In populations with a (mild) iodine insufficiency at present or in the past, TSH decreases with age and $\mathrm{FT}_{4}$ increases with age $(30,31,32)$.

The aim of this study was to investigate the influence of age on the association between thyroid function and mortality, in a population in which TSH decreases and $\mathrm{FT}_{4}$ increases with age.

\section{Subjects and methods}

\section{Study participants}

The subjects of this study are participants of the Nijmegen Biomedical Study (NBS), a large population-based survey carried out in 2002-2003 in Nijmegen, a municipality in the eastern part of The Netherlands. Details of this study have been described before (30). In the past, mild iodine deficiency was present in this part of The Netherlands $(33,34)$. Currently, the iodine status of this population is considered to be adequate $(35,36)$. Approval to conduct the study was obtained from the Institutional Review Board. A total of 22451 age- and sex-stratified randomly selected adults received a questionnaire on gender, age, weight, height, lifestyle, medical history and the use of medication. Of each 5-year age-group, 750 men and 750 women were invited to participate. We excluded the subjects with known thyroid disease (overt/subclinical thyrotoxicosis or hypothyroidism), those who used thyromimetic and/or thyrostatic drugs, and those who had former thyroid surgery and/or radioactive iodine treatment. Also, participants who were pregnant or used medications interfering with thyroid function, such as lithium, amiodarone, oral glucocorticosteroids, kelp, dopamine agonists and/or opiates, were excluded because of the possible influence of pregnancy and these medications on serum $\mathrm{TSH}$ and $\mathrm{FT}_{4}$ levels.

Data on vital status and changes in address were obtained from the municipal registers at set times. For respondents who died, the date of death was traced through death certificates from municipal registers until October 2012. When subjects moved out of the region and no data on vital status could be obtained anymore, data were used for analyses until the date of moving out (interval censuring).

\section{Laboratory methods}

Blood samples were taken in 2002-2003 in order to measure $\mathrm{TSH}, \mathrm{FT}_{4}$ and peroxidase antibodies levels. Serum TSH was measured by an immunoluminometric assay on a random-access analyser (Architect; Abbott Diagnostics Division). The reference interval used in our laboratory is 0.4-4.0 mIU/1. Serum $\mathrm{FT}_{4}$ was measured with a luminescence enzyme immunoassay on a random-access assay system (Vitros ECI; Ortho Clinical Diagnostics, Rochester, NY, USA). Our laboratory reference interval is $8.0-22.0 \mathrm{pmol} / \mathrm{l}$. TPOAbs were measured with a fluorescence immunoenzymometric assay for the quantitative measurement of the IgG class of anti-thyroid peroxidase antibodies (AxSYM Anti-TPO; Abbott Diagnostics Division). The reference interval was defined as $<12 \mathrm{kIU} / \mathrm{l}$ (data provided by manufacturer). Thyroid function was classified as overt thyrotoxicosis if TSH was $<0.4 \mathrm{mIU} / 1$ and $\mathrm{FT}_{4}$ was $>22 \mathrm{pmol} / \mathrm{l}$, and it was classified as subclinical thyrotoxicosis if TSH was $<0.4 \mathrm{mIU} / \mathrm{l}$ and $\mathrm{FT}_{4}$ was $\geq 8$ and $\leq 22 \mathrm{pmol} / \mathrm{l}$. Thyroid function was classified as overt hypothyroidism if TSH was $>4.0 \mathrm{mIU} / \mathrm{l}$ and $\mathrm{FT}_{4}$ was $<8 \mathrm{pmol} / \mathrm{l}$ and as subclinical hypothyroidism if TSH was $>4.0 \mathrm{mIU} / 1$ and $\mathrm{FT}_{4}$ was $\geq 8$ and $\leq 22 \mathrm{pmol} / \mathrm{l}$. When both $\mathrm{TSH}$ and $\mathrm{FT}_{4}$ were within the normal range, thyroid function was classified as euthyroidism. When either TSH or $\mathrm{FT}_{4}$ was not within the normal range, thyroid function was classified as thyroid dysfunction.

\section{Statistical analyses}

We constructed Kaplan-Meier curves to compare unadjusted survival ratios of participants according to 
the thyroid function class and according to subclasses of $\mathrm{TSH}$ and $\mathrm{FT}_{4}$ within the normal range. For this purpose, we stratified the euthyroid participants according to the TSH level (TSH 0.4-1.0, 1.0-2.0, 2.0-3.0 and 3.0-4.0 mIU/l) and $\mathrm{FT}_{4}$ level $(8.0-11.5,11.5-15.0,15.0-18.5$ and $18.5-22.0 \mathrm{pmol} / \mathrm{l})$.

Using a Cox proportional hazards model, we calculated adjusted hazard ratios (HRs) with a 95\% CI of mortality by thyroid function classes, using the euthyroid group as the reference group. In addition, we calculated adjusted $\mathrm{HR}$ with a $95 \% \mathrm{CI}$ of mortality of the TSH and $\mathrm{FT}_{4}$ subclasses within the normal range in euthyroid subjects. We adjusted all analyses for possible confounders, selecting the following factors for adjustment because of their known or presumed relation with both thyroid function and mortality: age, gender, BMI, smoking status, medical history of hypertension, hypercholesterolaemia, diabetes mellitus, cardiovascular disease, cancer, deep venous thrombosis, asthma/chronic obstructive pulmonary disease, rheumatoid arthritis, renal and/or liver disease. Log minus log plots and inclusion of timedependent covariates in the Cox model were used to check the proportional hazards model assumption, which was not violated in any of the models. To assess the influence of age on the relationship between mortality and thyroid function, we subdivided the participants into three age groups: aged $<65,65-80$ and $\geq 80$ years and performed the analyses as described earlier in each subgroup. All statistical analyses were performed using STATA, version 11 (StataCorp., College Station, TX, USA).

\section{Results}

A total of 9350 subjects responded to the invitation to fill out the questionnaire (response rate: $42 \%$ ). Of these responders, 6.434 (69\%) subjects gave permission for blood withdrawal. The demographic characteristics of the non-responders differed only slightly from the responders who gave permission for blood withdrawal: the mean age was 53.1 vs 56.1 years respectively, the percentage of women was 50.2 vs $53.8 \%$. We excluded 47 pregnant women and 212 subjects using medication interfering with thyroid function. In addition, we excluded 322 subjects because of previously known thyroid disease. Of 37 subjects, the date of blood collection was missing or the follow-up was completely missing and they were also excluded. The median follow-up time was 9.4 years. Of the remaining 5816 participants, 775 subjects (13.3\%) died within the follow-up period of the study. Table 1 shows the population characteristics. Data on BMI were missing in 137 subjects, data on smoking status were missing in 17 subjects and data on medical history were missing in 54 subjects.

Table 1 Characteristics of the study population.

\begin{tabular}{|c|c|c|c|c|}
\hline Characteristic & $\begin{array}{c}\text { Total } \\
(n=5816)\end{array}$ & $\begin{array}{c}\text { Age }<65 \text { years } \\
(n=3773)\end{array}$ & $\begin{array}{c}\text { Age } 65-80 \text { years } \\
(n=1550)\end{array}$ & $\begin{array}{c}\text { Age } \geq 80 \text { years } \\
(n=493)\end{array}$ \\
\hline Number of deaths & $775(13.3 \%)$ & $110(2.9 \%)$ & $362(23.4 \%)$ & $303(61.5 \%)$ \\
\hline Age (years) ${ }^{a}$ & $55.7 \pm 17.9$ & $45.3 \pm 12.9$ & $71.9 \pm 4.3$ & $84.0 \pm 3.1$ \\
\hline Male & $2.761(47.5 \%)$ & $1.611(42.7 \%)$ & $875(56.5 \%)$ & $275(55.8 \%)$ \\
\hline BMI $\left(\mathrm{kg} / \mathrm{m}^{2}\right)$ & $25.1 \pm 4.0$ & $24.8 \pm 4.2$ & $25.9 \pm 3.7$ & $25.2 \pm 3.8$ \\
\hline Smoking $(n(\%))$ & $1.301(22.4 \%)$ & $1.004(26.7 \%)$ & $241(15.6 \%)$ & $56(11.4 \%)$ \\
\hline \multicolumn{5}{|l|}{ Medical history of } \\
\hline COPD/asthma (\%) & $712(12.4 \%)$ & $443(11.8 \%)$ & $203(13.3 \%)$ & $66(13.6 \%)$ \\
\hline CVD (\%) & $577(10.0 \%)$ & $133(3.6 \%)$ & $312(20.4 \%)$ & $132(27.1 \%)$ \\
\hline Rheumatic disease (\%) & $482(8.4 \%)$ & $192(5.1 \%)$ & $220(14.4 \%)$ & $70(14.4 \%)$ \\
\hline Cancer (\%) & $446(7.7 \%)$ & $162(4.3 \%)$ & $200(13.1 \%)$ & $84(17.3 \%)$ \\
\hline Diabetes mellitus (\%) & $315(5.5 \%)$ & $110(2.9 \%)$ & $154(10.1 \%)$ & $51(10.5 \%)$ \\
\hline Hypertension (\%) & $1365(25.5 \%)$ & $649(18.0 \%)$ & $547(40.9 \%)$ & $169(41.5 \%)$ \\
\hline Hypercholesterolaemia (\%) & $899(17.1 \%)$ & $407(11.4 \%)$ & $429(33.0 \%)$ & $63(17.0 \%)$ \\
\hline VTE (\%) & $221(3.8 \%)$ & $66(1.8 \%)$ & $99(6.5 \%)$ & $56(11.5 \%)$ \\
\hline Kidney disease (\%) & $171(3.0 \%)$ & $85(2.3 \%)$ & $51(3.3 \%)$ & $35(7.1 \%)$ \\
\hline Liver disease (\%) & $134(2.3 \%)$ & $89(2.4 \%)$ & $35(2.3 \%)$ & $10(2.1 \%)$ \\
\hline TPOAbs positive & $735(12.6 \%)$ & $448(11.9 \%)$ & $234(15.1 \%)$ & $53(10.8 \%)$ \\
\hline TSH $(\mathrm{mlU} / \mathrm{l})^{\mathrm{b}}$ & $1.34(0.34-4.92)$ & $1.41(0.43-4.72)$ & $1.24(0.26-5.58)$ & $1.15(0.21-5.68)$ \\
\hline $\mathrm{FT}_{4}(\mathrm{pmol} / \mathrm{l})^{\mathrm{b}}$ & $13.3(9.7-18.2)$ & $13.0(9.4-17.4)$ & $13.6(9.9-19.0)$ & $14.3(10.3-19.3)$ \\
\hline
\end{tabular}

COPD, chronic obstructive pulmonary disease; CVD, cardiovascular disease; VTE, venous thromboembolism; TPOAbs, peroxidase antibodies; TSH, thyroidstimulating hormone; $\mathrm{FT}_{4}$, free thyroxine.

aplus-minus values are mean \pm s.D.

${ }^{\mathrm{b}}$ Geometric mean, 2.5-97.5th percentiles. 
The Kaplan-Meier survival curves for different thyroid categories are depicted in Fig. 1. The lowest survival rates were observed in subjects with thyrotoxicosis. Subclinical thyrotoxicosis was also associated with lower survival rates, especially in subjects aged $<65$ years. The KaplanMeier survival curves for $\mathrm{TSH}$ and $\mathrm{FT}_{4}$ subclasses in euthyroid subjects are shown in Figs 2 and 3. The lowest survival rates were observed in subjects aged $\geq 65$ years with a high-normal $\mathrm{FT}_{4}$ level (18.5-22.0 pmol/l), but no difference in survival rates was found between $\mathrm{FT}_{4}$ subclasses in subjects aged $<65$ years.

Table 2 presents the number of deaths within the follow-up period and the HRs by thyroid function class, stratified for age and adjusted for possible confounders. Seven subjects had a serum TSH $>0.4 \mathrm{mIU} / \mathrm{l}$ and $\mathrm{FT}_{4}$ $>22 \mathrm{pmol} / \mathrm{l}$, eight subjects had a serum TSH value of $<0.4 \mathrm{mIU} / \mathrm{l}$ and $\mathrm{FT}_{4}<8 \mathrm{pmol} / \mathrm{l}$ and were not assigned to one of the thyroid function classes. They were assigned to the thyroid dysfunction group. Thyroid dysfunction (either $\mathrm{TSH}$ or $\mathrm{FT}_{4}$ not within the normal range) was associated with a higher mortality in comparison with euthyroidism: 21.3 vs 12.7\%, HR 1.3 (95\% CI 1.0-1.6) after adjustment for possible confounders. The difference was more distinct in subjects aged <65 years: 5.3 vs $2.8 \%$, HR 1.7 (95\% CI 0.9-3.2). The results of subjects with overt hypothyroidism and thyrotoxicosis should be interpreted cautiously, as only a limited number of participants were found to have an overt thyroid dysfunction. Mortality was higher in subjects with overt thyrotoxicosis in comparison with subjects with euthyroidism: 55.6 vs $12.7 \%$, HR 8.2 (95\% CI 3.4-19.7). Subclinical thyrotoxicosis was only associated with mortality in subjects aged $<65$ years, 9.7 vs $2.8 \%$ (HR 2.5 (95\% CI 1.1-5.7)), but not in subjects aged 65 years or older.

Table 3 presents the number of deaths and the HRs in euthyroid subjects by TSH and $\mathrm{FT}_{4}$ subclasses within the normal range. $\mathrm{A} \mathrm{FT}_{4}$ level in the high-normal range (18.5-22 pmol/l) was associated with a higher mortality in comparison with $\mathrm{FT}_{4}$ levels in the middle range $(11.5-15.0 \mathrm{pmol} / \mathrm{l}): 39.3$ vs $11.0 \%$, HR 1.6 (95\% CI 1.1-2.4). Subanalysis by age showed that this association was only present in subjects aged $\geq 80$ years (HR 1.7 (95\% CI 1.0-2.8)). TSH levels within the high-normal range (TSH 3.0-4.0 mIU/l) were associated with a higher mortality in comparison with TSH levels in the middle range $(1.0-2.0 \mathrm{mIU} / \mathrm{l})$ in subjects aged $>80$ years: $83.3 \mathrm{vs}$ $57.4 \%$, HR 1.8 (95\% CI 1.0-3.1), which was not the case in subjects aged $<80$ years.

There was no association between the presence of TPOAbs and mortality in the total population

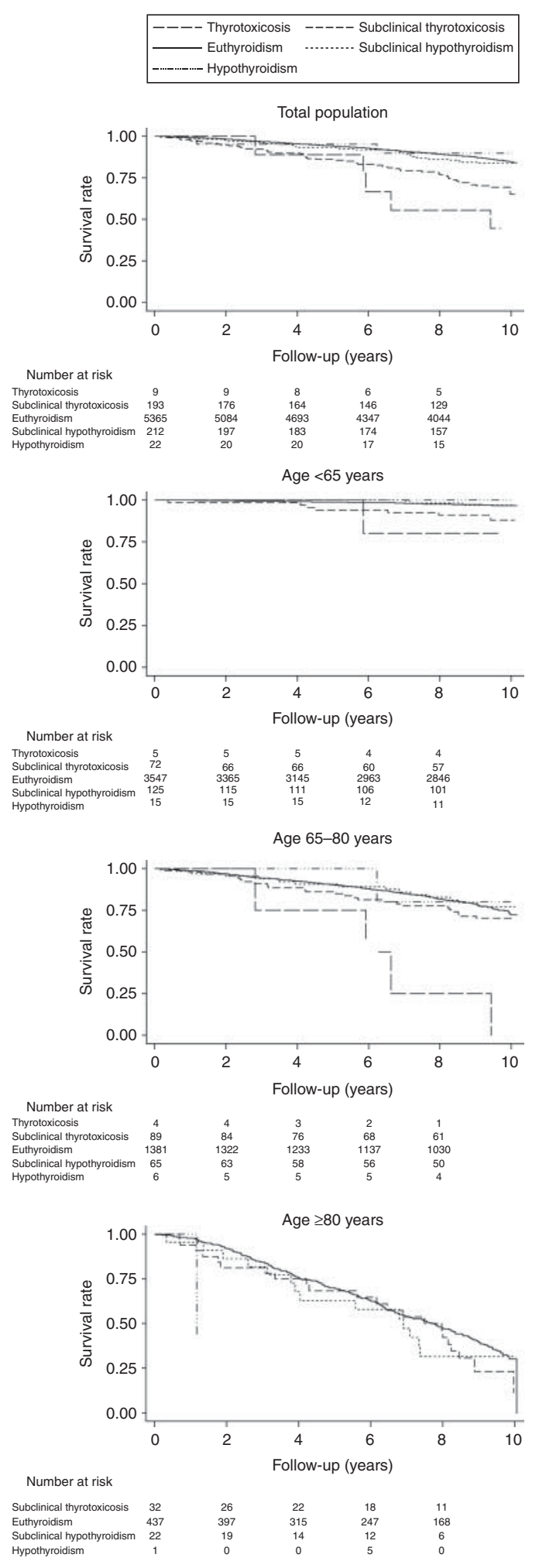

Figure 1

Kaplan-Meier survival curves by thyroid function class, stratified for age. 


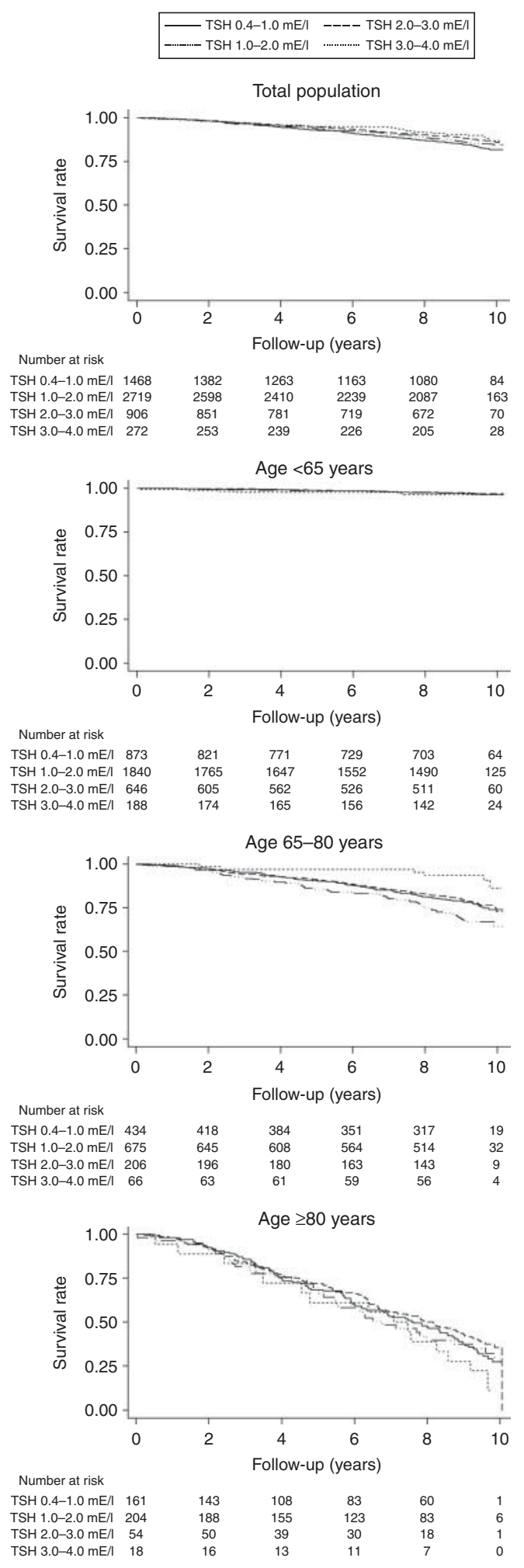

Figure 2

Kaplan-Meier survival curves by TSH subclass in euthyroid subjects, stratified for age.
(HR 0.9, 95\% CI 0.7-1.2) nor in the different age groups (data not shown).

\section{Discussion}

This large population-based study, comprising randomly selected adults of all age groups, provided the opportunity to investigate the influence of age on the relationship between thyroid function and mortality in a population in which TSH decreases and $\mathrm{FT}_{4}$ increases with age (30).

Regarding the relationship between thyroid function in euthyroid subjects and mortality, the association between higher $\mathrm{FT}_{4}$ levels within the normal range and mortality was only present in the oldest participants. These findings are similar to the results of the Leiden $85+$ Study, the studies of Waring et al. and van den Beld et al. $(24,27,29)$. The reason why higher $\mathrm{FT}_{4}$ but not lower TSH levels within the normal range predict mortality in this oldest group is not clear. As previously hypothesised, these results might suggest that there is a change in pituitary TSH set point in the elderly, e.g. an altered pituitary sensitivity for thyroid hormones, and higher $\mathrm{FT}_{4}$ levels do not cause the same TSH suppression as in younger individuals. Another explanation could be that higher $\mathrm{FT}_{4}$ levels reflect a decreased $5^{\prime}$-deiodination due to non-thyroidal illness and are associated with lower triiodothyronine $\left(\mathrm{T}_{3}\right)$ levels. However, as shown by Waring et al. and in the Leiden $85+$ Study, the relationship between $\mathrm{FT}_{4}$ and mortality seems to be independent of the $\mathrm{T}_{3}$ level $(24,29)$. In our study, all the euthyroid subjects aged $>80$ years with a $\mathrm{FT}_{4}$ level of $18.5-22.0 \mathrm{pmol} / \mathrm{l}$ had a TSH level $<2.0 \mathrm{mIU} / \mathrm{l}$. These subjects comprised only a small subset of the subjects with a TSH level $<2.0 \mathrm{mE} / \mathrm{l}$. The majority of the subjects in this oldest group with a low-normal TSH had a low- or middle-normal $\mathrm{FT}_{4}$ levels (8-18.5 pmol/l) and those subjects did not have a higher mortality. Therefore, $\mathrm{FT}_{4}$ seems to be a better marker to predict mortality in elderly than TSH. On the other hand, a high-normal TSH but not a low-normal $\mathrm{FT}_{4}$ level was also associated with mortality in the elderly. Our study was a cross-sectional survey and no causal relationships can be shown. Prospective intervention trials are needed to assess the targets for treatment in this subgroup.

Our study provides new insights for the ongoing debate about the upper limit of the reference range of TSH, especially in the elderly. It has been suggested to increase the upper limit in the elderly $(37,38)$. Arguments for this recommendation are the increase in TSH with age in several (iodine sufficient) populations and the high amount of older, TPOAbs-negative subjects with TSH 


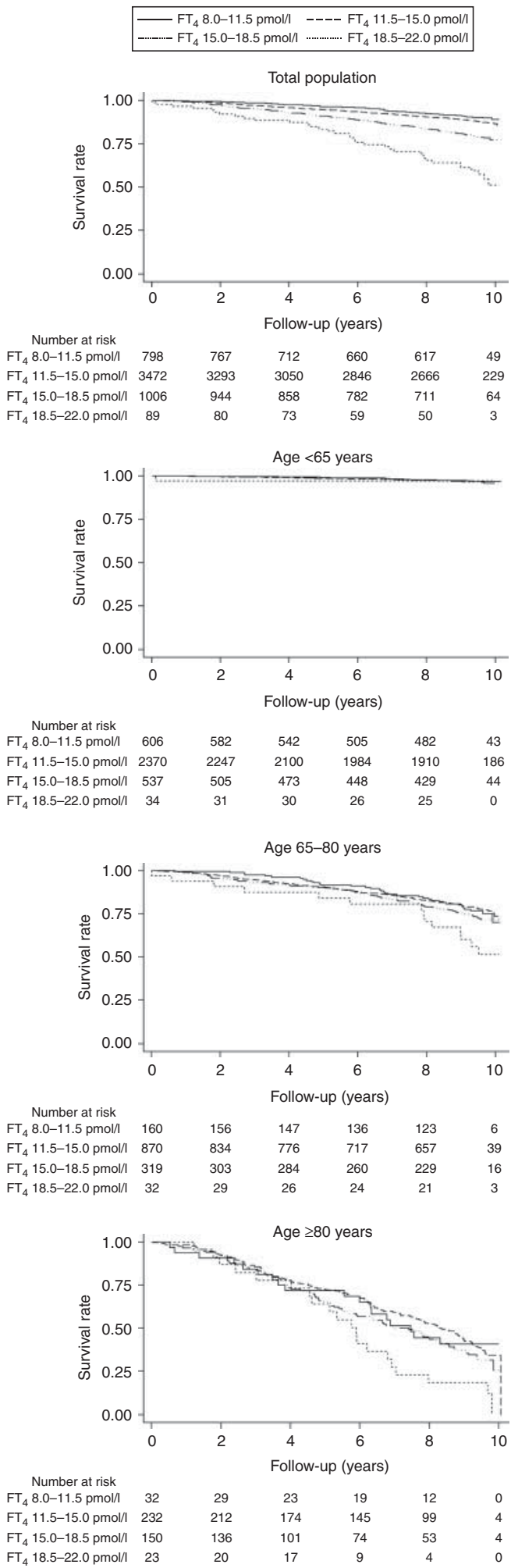

Figure 3

Kaplan-Meier survival curves by $\mathrm{FT}_{4}$ subclass in euthyroid subjects, stratified for age. above the upper limit of the currently used reference range $(29,38,39)$. However, in our population TSH decreases and $\mathrm{FT}_{4}$ increases with age probably due to mild iodine insufficiency in the past, leading to autonomous function of the thyroid (despite the adequate iodine status at present, achieved after increasing the amount of iodised salt in bakeries in 1982) (30, 40). Moreover, in our population, a high-normal TSH level was associated with mortality in the elderly. So, the suggestion of increasing the upper limit of the reference range of TSH in the elderly seems in appropriate for our population. Reference ranges might be different not only for different races or ages, as previously suggested, but also for different populations. On the other hand, despite the fact that an increase in $\mathrm{FT}_{4}$ levels with age appears to be 'normal' in our population (when using the population distribution to assess what is normal), we found that in the elderly a higher $\mathrm{FT}_{4}$ level within the normal range was associated with mortality. This implies that one should not only use the population distribution but also know the clinical consequences of thyroid hormone levels to determine the reference ranges.

We found inconclusive and conflicting results regarding the relationship between TSH within the normal range and mortality in subjects aged $65-80$ years. These results do not seem to make sense from a biological point of view and it is possible that some of the significant results might be due to chance due to multiple testing. These findings reflect the discrepant results of previous studies investigating the relationship between thyroid function and mortality and endorse the current controversy regarding this topic.

As inevitable in a population-based study, the number of subjects with subclinical and overt thyroid dysfunction were limited. Despite the small number of participants with subclinical thyrotoxicosis $(n=193)$, we observed an association between subclinical thyrotoxicosis and mortality in younger subjects only, not in participants aged $\geq 65$ years. An explanation for this finding could be the fact that in older subjects there is a larger contribution of other cardiovascular risk factors, such as age, and that there is more competing mortality (independent of thyroid function).

Similar to these results, meta-analyses by Ochs et al. and Razvi et al. reported no association between mortality and subclinical hypothyroidism in the total population, but they did find an association between subclinical hypothyroidism and mortality in younger participants (aged $<65$ years) $(17,28)$. We could not detect a significant relationship between subclinical hypothyroidism and mortality. We cannot exclude that we had too limited power for this subgroup to show a modest 
Table 2 Number of deaths and the hazard ratios by thyroid function classification. Cox regression adjusted for age, gender, BMI, smoking status, medical history of hypertension, hypercholesterolaemia, diabetes mellitus, cardiovascular disease, cancer, deep venous thrombosis, asthma/COPD, rheumatoid arthritis, renal and/or liver disease.

\begin{tabular}{|c|c|c|c|c|c|c|c|c|}
\hline & \multicolumn{2}{|c|}{ Total population } & \multicolumn{2}{|c|}{$<65$ years } & \multicolumn{2}{|c|}{ 65-80 years } & \multicolumn{2}{|c|}{$\geq 80$ years } \\
\hline & $\begin{array}{l}\text { Deaths } \\
(\%(n))\end{array}$ & $\mathrm{HR}(95 \% \mathrm{Cl})$ & $\begin{array}{l}\text { Deaths } \\
(\%(n))\end{array}$ & $\mathrm{HR}(95 \% \mathrm{Cl})$ & $\begin{array}{l}\text { Deaths } \\
(\%(n))\end{array}$ & $\mathrm{HR}(95 \% \mathrm{Cl})$ & $\begin{array}{l}\text { Deaths } \\
(\%(n))\end{array}$ & $\mathrm{HR}(95 \% \mathrm{Cl})$ \\
\hline \multirow[t]{2}{*}{ Euthyroidism } & $12.7 \%$ & Reference & $2.8 \%$ & Reference & $23.0 \%$ & Reference & $60.4 \%$ & Reference \\
\hline & $679 / 5365$ & & $98 / 3547$ & & $317 / 1381$ & & $264 / 437$ & \\
\hline \multirow[t]{2}{*}{ Thyroid dysfunction } & $21.3 \%$ & $1.3(1.0-1.6)$ & $5.3 \%$ & $1.7(0.9-3.2)$ & $26.6 \%$ & $1.3(0.9-1.7)$ & $69.6 \%$ & $1.3(0.9-1.8)$ \\
\hline & $96 / 451$ & & $12 / 226$ & & $45 / 169$ & & $39 / 56$ & \\
\hline \multirow[t]{2}{*}{ Overt thyrotoxicosis } & $55.6 \%$ & $8.2(3.4-19.7)$ & $20.0 \%$ & $13.4(1.8-98.1)$ & $100 \%$ & $7.8(2.9-21.2)$ & $0.0 \%$ & No subjects \\
\hline & $5 / 9$ & & $1 / 5$ & & $4 / 4$ & & $0 / 0$ & \\
\hline \multirow[t]{2}{*}{ Subclinical thyrotoxicosis } & $28.5 \%$ & $1.2(0.9-1.6)$ & $9.7 \%$ & $2.5(1.1-5.7)$ & $28.1 \%$ & $1.3(0.8-2.0)$ & $71.9 \%$ & $1.1(0.7-1.8)$ \\
\hline & $55 / 193$ & & $7 / 72$ & & $25 / 89$ & & $23 / 32$ & \\
\hline \multirow[t]{2}{*}{ Subclinical hypothyroidism } & $14.6 \%$ & $1.2(0.8-1.7)$ & $2.4 \%$ & $0.9(0.3-3.0)$ & $21.5 \%$ & $1.0(0.6-1.8)$ & $63.6 \%$ & $1.5(0.9-2.5)$ \\
\hline & $31 / 212$ & & $3 / 125$ & & $14 / 65$ & & $14 / 22$ & \\
\hline \multirow[t]{2}{*}{ Overt hypothyroidism } & $9.1 \%$ & $1.6(0.4-6.6)$ & $0.0 \%$ & No deaths & $16.7 \%$ & $1.6(0.2-11.7)$ & $100 \%$ & $35.1(4-268)$ \\
\hline & $2 / 22$ & & $0 / 15$ & & $1 / 6$ & & $1 / 1$ & \\
\hline
\end{tabular}

relationship with mortality. Recently, six meta-analyses regarding the relationship between thyroid function class and mortality have reported conflicting results. Volzke et al. (21) concluded that the current available evidence for a causal relation of thyroid dysfunction and mortality is weak due to highly discrepant results of previous studies, probably due to confounding and selection bias. Singh et al. (20) and Rodondi et al. (19) found an association between cardiovascular mortality and subclinical hypothyroidism, whereas Haentjens et al. (16) only found an association between subclinical hyperthyroidism and all-cause mortality. Ochs et al. and
Razvi et al. found no association between mortality and subclinical hypothyroidism in the total population, but they did find an association between subclinical hypothyroidism and mortality in younger participants (aged $<65$ years) $(17,18)$. These discordant results might be caused by varying methods of adjustment for confounders and the clinical heterogeneity among the studies due to differences in populations. As we have shown in this study, the age of the study participants can be of major influence on the outcome of the study and therefore might be one factor explaining the discrepancies between the studies.

Table 3 Number of deaths and the hazard ratios in euthyroid subjects by TSH and $\mathrm{FT}_{4}$ subclasses within the normal range. Cox regression adjusted for age, gender, BMI, smoking status, medical history of hypertension, hypercholesterolaemia, diabetes mellitus, cardiovascular disease, cancer, deep venous thrombosis, asthma/COPD, rheumatoid arthritis, renal and/or liver disease.

\begin{tabular}{|c|c|c|c|c|c|c|c|c|}
\hline & \multicolumn{2}{|c|}{ Total population } & \multicolumn{2}{|c|}{$<65$ years } & \multicolumn{2}{|c|}{$65-80$ years } & \multicolumn{2}{|c|}{$\geq 80$ years } \\
\hline & $\begin{array}{l}\text { Deaths } \\
(\%(n))\end{array}$ & $\mathrm{HR}(95 \% \mathrm{Cl})$ & $\begin{array}{l}\text { Deaths } \\
(\%(n))\end{array}$ & $\mathrm{HR}(95 \% \mathrm{Cl})$ & $\begin{array}{l}\text { Deaths } \\
(\%(n))\end{array}$ & HR $(95 \% \mathrm{Cl})$ & $\begin{array}{l}\text { Deaths } \\
(\%(n))\end{array}$ & $\mathrm{HR}(95 \% \mathrm{Cl})$ \\
\hline TSH $0.4-1.0 \mathrm{mIU} / \mathrm{l}$ & $\begin{array}{c}15.1 \% \\
221 / 1468\end{array}$ & $1.1(0.9-1.3)$ & $\begin{array}{c}3.0 \% \\
26 / 873\end{array}$ & $0.9(0.5-1.4)$ & $\begin{array}{l}22.6 \% \\
98 / 434\end{array}$ & $1.1(0.9-1.4)$ & $\begin{array}{l}60.3 \% \\
97 / 161\end{array}$ & $1.1(0.9-1.5)$ \\
\hline TSH $1.0-2.0 \mathrm{mIU} / \mathrm{l}$ & $\begin{array}{c}11.5 \% \\
313 / 2719\end{array}$ & Reference & $\begin{array}{c}2.6 \% \\
48 / 1840\end{array}$ & Reference & $\begin{array}{c}21.9 \% \\
148 / 675\end{array}$ & Reference & $\begin{array}{c}57.4 \% \\
117 / 204\end{array}$ & Reference \\
\hline TSH 2.0-3.0 mIU/l & $\begin{array}{c}13.0 \% \\
118 / 906\end{array}$ & $1.3(1.0-1.6)$ & $\begin{array}{c}2.8 \% \\
18 / 646\end{array}$ & $1.2(0.7-2.2)$ & $\begin{array}{l}31.6 \% \\
65 / 206\end{array}$ & $1.5(1.1-2.0)$ & $\begin{array}{c}64.8 \% \\
35 / 54\end{array}$ & $1.1(0.7-1.6)$ \\
\hline TSH 3.0-4.0 mIU/l & $\begin{array}{c}9.9 \% \\
27 / 272\end{array}$ & $0.9(0.6-1.3)$ & $\begin{array}{l}3.2 \% \\
6 / 188\end{array}$ & $1.4(0.6-3.3)$ & $\begin{array}{c}9.1 \% \\
6 / 66\end{array}$ & $0.2(0.1-0.7)$ & $\begin{array}{c}83.3 \% \\
15 / 18\end{array}$ & $1.8(1.0-3.1)$ \\
\hline $\mathrm{FT}_{4} 8.0-11.5 \mathrm{pmol} / \mathrm{l}$ & $\begin{array}{c}8.8 \% \\
70 / 798\end{array}$ & $1.1(0.8-1.4)$ & $\begin{array}{c}2.6 \% \\
16 / 606\end{array}$ & $1.0(0.6-1.7)$ & $\begin{array}{l}22.5 \% \\
36 / 160\end{array}$ & $1.1(0.8-1.6)$ & $\begin{array}{c}56.3 \% \\
18 / 32\end{array}$ & $1.0(0.6-1.8)$ \\
\hline $\mathrm{FT}_{4} 11.5-15 \mathrm{pmol} / \mathrm{l}$ & $\begin{array}{c}11.0 \% \\
383 / 3472\end{array}$ & Reference & $\begin{array}{c}2.7 \% \\
64 / 2370\end{array}$ & Reference & $\begin{array}{c}21.3 \% \\
185 / 870\end{array}$ & Reference & $\begin{array}{c}57.8 \% \\
134 / 232\end{array}$ & Reference \\
\hline $\mathrm{FT}_{4} 15-18.5 \mathrm{pmol} / \mathrm{l}$ & $\begin{array}{c}19.0 \% \\
191 / 1006\end{array}$ & $1.1(0.9-1.3)$ & $\begin{array}{c}3.2 \% \\
17 / 537\end{array}$ & $0.8(0.4-1.3)$ & $\begin{array}{l}25.7 \% \\
82 / 319\end{array}$ & $1.2(0.9-1.5)$ & $\begin{array}{l}61.3 \% \\
92 / 150\end{array}$ & $1.1(0.8-1.5)$ \\
\hline $\mathrm{FT}_{4} 18.5-22 \mathrm{pmol} / \mathrm{l}$ & $\begin{array}{c}39.3 \% \\
35 / 89\end{array}$ & $1.6(1.1-2.4)$ & $\begin{array}{c}2.9 \% \\
1 / 34\end{array}$ & $1.0(0.1-7.2)$ & $\begin{array}{c}43.8 \% \\
14 / 32\end{array}$ & $1.6(0.9-3.1)$ & $\begin{array}{c}87.0 \% \\
20 / 23\end{array}$ & $1.7(1.0-2.9)$ \\
\hline
\end{tabular}


Our study has a few limitations. We did not measure $\mathrm{T}_{3}$, so we might have missed some cases of overt thyrotoxicosis in subjects with normal $\mathrm{FT}_{4}$ and elevated $\mathrm{T}_{3}$ and misclassified those subjects as having a subclinical thyrotoxicosis. Second, analyses were based on one single measurement of $\mathrm{TSH}$ and $\mathrm{FT}_{4}$. Owing to the variation of TSH and $\mathrm{FT}_{4}$, the relationship between thyroid function and mortality might be underestimated as a result of regression dilution bias (41). In addition, transient thyroid abnormality such as thyroiditis may have been misclassified. Third, at baseline, we excluded subjects with known thyroid disease and those who used thyromimetic and/or thyrostatic drugs. However, we did not assess whether treatment with thyrostatic or thyromimetic drugs was started during follow-up. Finally, we had no data on the causes of death so we could not perform cause-specific mortality analysis.

In conclusion, age influences the relationship between thyroid function and mortality. Subclinical thyrotoxicosis was associated with mortality in younger subjects only. In elderly, within the normal range of thyroid function, both high-normal $\mathrm{FT}_{4}$ and high-normal TSH levels were associated with mortality. The fact that previous studies comprised specific and different age groups can, at least in part, explain the discrepant findings and the remaining controversy concerning the relationship between thyroid function and mortality.

\section{Declaration of interest}

The authors declare that there is no conflict of interest that could be perceived as prejudicing the impartiality of the research reported.

\section{Funding}

This research did not receive any specific grant from any funding agency in the public, commercial or not-for-profit sector.

\section{References}

1 Lazarus JH. Hyperthyroidism. Lancet 1997349 339-343. (doi:10.1016/ S0140-6736(96)08015-4)

2 Lindsay RS \& Toft AD. Hypothyroidism. Lancet 1997349 413-417. (doi:10.1016/S0140-6736(97)80050-5)

3 Surks MI, Ortiz E, Daniels GH, Sawin CT, Col NF, Cobin RH, Franklyn JA, Hershman JM, Burman KD, Denke MA et al. Subclinical thyroid disease: scientific review and guidelines for diagnosis and management. Journal of the American Medical Association 2004291 228-238. (doi:10.1001/jama.291.2.228)

4 Biondi B \& Cooper DS. The clinical significance of subclinical thyroid dysfunction. Endocrine Reviews 200829 76-131. (doi:10.1210/er. 2006-0043)

5 Imaizumi M, Akahoshi M, Ichimaru S, Nakashima E, Hida A, Soda M, Usa T, Ashizawa K, Yokoyama N, Maeda R et al. Risk for ischemic heart disease and all-cause mortality in subclinical hypothyroidism. Journal of Clinical Endocrinology and Metabolism 200489 3365-3370. (doi:10.1210/ jc.2003-031089)

6 Razvi S, Weaver JU, Vanderpump MP \& Pearce SH. The incidence of ischemic heart disease and mortality in people with subclinical hypothyroidism: reanalysis of the Whickham Survey cohort. Journal of Clinical Endocrinology and Metabolism 201095 1734-1740. (doi:10.1210/ jc.2009-1749)

7 Sgarbi JA, Matsumura LK, Kasamatsu TS, Ferreira SR \& Maciel RM. Subclinical thyroid dysfunctions are independent risk factors for mortality in a 7.5-year follow-up: the Japanese-Brazilian thyroid study. European Journal of Endocrinology 2010162 569-577. (doi:10.1530/ EJE-09-0845)

8 Walsh JP, Bremner AP, Bulsara MK, O'Leary P, Leedman PJ, Feddema P $\&$ Michelangeli V. Subclinical thyroid dysfunction as a risk factor for cardiovascular disease. Archives of Internal Medicine 2005165 2467-2472. (doi:10.1001/archinte.165.21.2467)

9 McQuade C, Skugor M, Brennan DM, Hoar B, Stevenson C \& Hoogwerf BJ. Hypothyroidism and moderate subclinical hypothyroidism are associated with increased all-cause mortality independent of coronary heart disease risk factors: a PreCIS database study. Thyroid 201121 837-843. (doi:10.1089/thy.2010.0298)

10 Tseng FY, Lin WY, Lin CC, Lee LT, Li TC, Sung PK \& Huang KC. Subclinical hypothyroidism is associated with increased risk for all-cause and cardiovascular mortality in adults. Journal of the American College of Cardiology 201260 730-737. (doi:10.1016/j.jacc.2012.03.047)

11 Bauer DC, Rodondi N, Stone KL \& Hillier TA. Thyroid hormone use, hyperthyroidism and mortality in older women. American Journal of Medicine 2007120 343-349.

12 Boekholdt SM, Titan SM, Wiersinga WM, Chatterjee K, Basart DC, Luben R, Wareham NJ \& Khaw KT. Initial thyroid status and cardiovascular risk factors: the EPIC-Norfolk prospective population study. Clinical Endocrinology 201072 404-410. (doi:10.1111/j.13652265.2009.03640.x)

13 Cappola AR, Fried LP, Arnold AM, Danese MD, Kuller LH, Burke GL, Tracy RP \& Ladenson PW. Thyroid status, cardiovascular risk, and mortality in older adults. Journal of the American Medical Association 2006295 1033-1041. (doi:10.1001/jama.295.9.1033)

14 de Jongh RT, Lips P, van Schoor NM, Rijs KJ, Deeg DJ, Comijs HC, Kramer MH, Vandenbroucke JP \& Dekkers OM. Endogenous subclinical thyroid disorders, physical and cognitive function, depression, and mortality in older individuals. European Journal of Endocrinology 2011 165 545-554. (doi:10.1530/EJE-11-0430)

15 Rodondi N, Newman AB, Vittinghoff E, de Rekeneire N, Satterfield S, Harris TB \& Bauer DC. Subclinical hypothyroidism and the risk of heart failure, other cardiovascular events, and death. Archives of Internal Medicine 2005165 2460-2466. (doi:10.1001/archinte.165.21.2460)

16 Haentjens P, Van Meerhaeghe A, Poppe K \& Velkeniers B. Subclinical thyroid dysfunction and mortality: an estimate of relative and absolute excess all-cause mortality based on time-to-event data from cohort studies. European Journal of Endocrinology 2008159 329-341. (doi:10.1530/EJE-08-0110)

17 Ochs N, Auer R, Bauer DC, Nanchen D, Gussekloo J, Cornuz J \& Rodondi N. Meta-analysis: subclinical thyroid dysfunction and the risk for coronary heart disease and mortality. Annals of Internal Medicine 2008148 832-845. (doi:10.7326/0003-4819-148-11-200806030-00225)

18 Razvi S, Shakoor A, Vanderpump M, Weaver JU \& Pearce SH. The influence of age on the relationship between subclinical hypothyroidism and ischemic heart disease: a metaanalysis. Journal of Clinical Endocrinology and Metabolism 200893 2998-3007. (doi:10.1210/jc. 2008-0167)

19 Rodondi N, den Elzen WP, Bauer DC, Cappola AR, Razvi S, Walsh JP, Asvold BO, Iervasi G, Imaizumi M, Collet TH et al. Subclinical hypothyroidism and the risk of coronary heart disease and mortality. Journal of the American Medical Association 2010304 1365-1374. (doi:10.1001/jama.2010.1361) 
20 Singh S, Duggal J, Molnar J, Maldonado F, Barsano CP \& Arora R. Impact of subclinical thyroid disorders on coronary heart disease, cardiovascular and all-cause mortality: a meta-analysis. International Journal of Cardiology 2008125 41-48. (doi:10.1016/j.ijcard.2007. 02.027)

21 Volzke H, Schwahn C, Wallaschofski H \& Dorr M. Review: The association of thyroid dysfunction with all-cause and circulatory mortality: is there a causal relationship? Journal of Clinical Endocrinology and Metabolism 200792 2421-2429. (doi:10.1210/jc.2007-0179) (doi:10.1210/jc.2007-0179)

22 Taylor PN, Razvi S, Pearce SH \& Dayan CM. Clinical review: A review of the clinical consequences of variation in thyroid function within the reference range. Journal of Clinical Endocrinology and Metabolism 201398 3562-3571. (doi:10.1210/jc.2013-1315)

23 Asvold BO, Bjoro T, Nilsen TI, Gunnell D \& Vatten LJ. Thyrotropin levels and risk of fatal coronary heart disease: the HUNT study. Archives of Internal Medicine 2008168 855-860. (doi:10.1001/archinte. 168.8.855)

24 Gussekloo J, van Exel E, de Craen AJ, Meinders AE, Frolich M \& Westendorp RG. Thyroid status, disability and cognitive function, and survival in old age. Journal of the American Medical Association 2004 292 2591-2599. (doi:10.1001/jama.292.21.2591)

25 Ittermann T, Haring R, Sauer S, Wallaschofski H, Dorr M, Nauck M \& Volzke H. Decreased serum TSH levels are not associated with mortality in the adult northeast German population. European Journal of Endocrinology 2010162 579-585. (doi:10.1530/EJE-09-0566)

26 Parle JV, Maisonneuve P, Sheppard MC, Boyle P \& Franklyn JA. Prediction of all-cause and cardiovascular mortality in elderly people from one low serum thyrotropin result: a 10-year cohort study. Lancet 2001358 861-865. (doi:10.1016/S01406736(01)06067-6)

27 van den Beld AW, Visser TJ, Feelders RA, Grobbee DE \& Lamberts SW. Thyroid hormone concentrations, disease, physical function, and mortality in elderly men. Journal of Clinical Endocrinology and Metabolism 200590 6403-6409. (doi:10.1210/jc.2005-0872)

28 Pereg D, Tirosh A, Elis A, Neuman Y, Mosseri M, Segev D, Lishner M \& Hermoni D. Mortality and coronary heart disease in euthyroid patients. American Journal of Medicine 2012826 826.e7-12. (doi:10.1016/ j.amjmed.2011.11.023)

29 Waring AC, Arnold AM, Newman AB, Buzkova P, Hirsch C \& Cappola AR. Longitudinal changes in thyroid function in the oldest old and survival: the cardiovascular health study all-stars study. Journal of Clinical Endocrinology and Metabolism 201297 3944-3950. (doi:10.1210/ jc.2012-2481)

30 Hoogendoorn EH, Hermus AR, deVegt F, Ross HA, Verbeek AL, Kiemeney LA, Swinkels DW, Sweep FC \& den HM. Thyroid function and prevalence of anti-thyroperoxidase antibodies in a population with borderline sufficient iodine intake: influences of age and sex. Clinical Chemistry 200652 104-111. (doi:10.1373/clinchem.2005.055194)

31 Waring AC, Harrison S, Samuels MH, Ensrud KE, LeBLanc ES, Hoffman AR, Orwoll E, Fink HA, Barrett-Connor E, Bauer DC et al.
Thyroid function and mortality in older men: a prospective study. Journal of Clinical Endocrinology and Metabolism 201297 862-870. (doi:10.1210/jc.2011-2684)

32 Laurberg P, Pedersen KM, Hreidarsson A, Sigfusson N, Iversen E \& Knudsen PR. Iodine intake and the pattern of thyroid disorders: a comparative epidemiological study of thyroid abnormalities in the elderly in Iceland and in Jutland. Journal of Clinical Endocrinology and Metabolism 199883 765-769. (doi:10.1210/jcem. 83.3.4624)

33 Brug J, Lowik MR, Wedel M \& Odink J. Iodide excretion before and after revision of goiter prophylaxis (Dutch Nutrition Surveillance System). European Journal of Clinical Nutrition 199246 671-678.

34 van Rees-Wortelboer MM, Schroder-van der Elst JP, Lycklama A \& van der Heide D. Iodine and goiter in The Netherlands. Nederlands Tijdschrift Voor Geneeskunde 1987131 1821-1824.

35 Hendriksen MA, van Raaij JM, Geleijnse JM, Wilson-van den Hooven C, Ocke MC \& van der A DL. Monitoring salt and iodine intakes in Dutch adults between 2006 and 2010 using $24 \mathrm{~h}$ urinary sodium and iodine excretions. Public Health Nutrition 201324 1-8. (doi:10.1017/ S1368980013001481)

36 Health Council of The Netherlands. In Towards Maintaining an Optimal Iodine Intake. Publication no 2008/14. The Hague, The Netherlands, 2008.

37 Selmer C, Olesen JB, Hansen ML, Lindhardsen J, Olsen AM, Madsen JC, Faber J, Hansen PR, Pedersen OD, Torp-Pedersen C et al. The spectrum of thyroid disease and risk of new onset atrial fibrillation: a large population cohort study. BMJ 2012345 e7895. (doi:10.1136/bmj. e7895)

38 Asvold BO, Vatten LJ, Midthjell K \& Bjoro T. Serum TSH within the reference range as a predictor of future hypothyroidism and hyperthyroidism: 11-year follow-up of the HUNT Study in Norway. Journal of Clinical Endocrinology and Metabolism 2012 97 93-99. (doi:10.1210/jc.2011-1724)

39 Bremner AP, Feddema P, Leedman PJ, Brown SJ, Beilby JP, Lim EM, Wilson SG, O'Leary PC \& Walsh JP. Age-related changes in thyroid function: a longitudinal study of a community-based cohort. Journal of Clinical Endocrinology and Metabolism 201297 1554-1562. (doi:10.1210/ jc.2011-3020)

40 van de Ven AC, Netea-Maier RT, Ross HA, van Herwaarden TA, Holewijn S, de Graaf J, Kiemeney BL, van Tienoven D, Wetzels JF, Smit JW et al. Longitudinal trends in thyroid function in relation to iodine intake: ongoing changes of thyroid function despite adequate current iodine status. European Journal of Endocrinology 2014170 49-54. (doi:10.1530/EJE-13-0589)

41 van de Ven AC, Netea-Maier RT, Medici M, Sweep FC, Ross HA, Hofman A, de Graaf J, Kiemeney LA, Hermus AR, Peeters RP et al. Underestimation of effect of thyroid function parameters on morbidity and mortality due to intra-individual variation. Journal of Clinical Endocrinology and Metabolism 201196 E2014-E2017. (doi:10.1210/ jc.2011-0680)

Received 31 December 2013

Revised version received 22 March 2014

Accepted 2 May 2014 